\title{
RECENT DEVELOPMENTS IN THE
}

\section{LAW ON GARNISHMENT IN ALBERTA:}

HUDSON'S BAY COMPANY v. B.D.C. LTD.

[1977] 3 Alta. L.R. (2d) 375

Upon receipt of a garnishee summons a garnishee in Alberta under Rule of Court 475(1) has 10 days in which to pay the debt owing to the judgment debtor into court, otherwise he must file an answer with the court explaining why no money has been paid in. Thus there is an established procedure which protects the garnishee by providing him with a means of exculpating himself and at the same time ensures that the judgment creditor knows in the appropriate case why the garnishee is withholding payment. The question is what happens if this procedure is ignored by a garnishee who neither pays into court nor explains his failure to do so?

This matter came before the District Court of Alberta on July 13, 1977, in the case of Hudson's Bay Company v. B.D.C. Ltd.' The facts were that the applicant, Hudson's Bay Company, had secured judgment in the amount of $\$ 2,470.88$ against one Kalmakoff, of which $\$ 1,559.03$ remained payable. The applicant then served the respondent, B.D.C. Ltd., with two garnishee summonses, but on both occasions the respondent failed to pay into court or to file an answer under 475(1). The applicant maintained that this represented a flagrant disregard of the legal process and asked for judgment for the full balance owing on the judgment debt, namely $\$ 1,559.03$, against the respondent. The respondent claimed that as there was little, if any, money payable under the garnishee summons, such a judgment would be inequitable. The respondent argued that the applicant had not in fact suffered any substantial damage and suggested that the application be rejected without order as to costs.

Under the Alberta Rules of Court, the court has discretion in situations such as the one existing here to give judgment "in such amount as may be proper" (475(4)). In this case the court was not prepared to use this discretion as either the applicant or the respondent had urged. It pointed out that the cases cited by the applicant dealt with the non-appearance in court of a garnishee, in default of which the garnishee was indeed held to have admitted liability for the full amount of the judgment debt. (Dixon v. Van Hummell; 2 Randall v. Lithgow ${ }^{3}$.) The court was prepared to accept the principle that non-appearance by the respondent would create a presumption of liability for the full judgment amount, but it emphasized that non-appearance cannot be equated with a failure to file an answer under Rule of Court 475(1). The court relied for this contention on the Alberta case of Hartt v. Edmonton Steam Laundry, ${ }^{4}$ a decision of $\mathrm{Mr}$. Justice Harvey in Supreme Court Chambers, and refused to accept the applicant's view that this case was inapplicable to the case at bar because it dealt with a garnishee summons before judgment. In the court's view there was no difference in principle between the two situations.

At the same time, the court agreed that there had been disregard for legal procedure which had put the applicant to unnecessary expense. Although it was not prepared to impose the heavy sanction upon the

\footnotetext{
1. [1977] 3 Alta. L.R. (2d) 375.

2. [1914] 6 W.W.R. 307 (Sask. C.A.).

3. (1884) 12 Q.B. 525.

4. (1909) 10 W.L.R. 604.
} 
respondent advocated by the applicant, it was not disposed either to overlook completely the respondent's conduct. The solution which the court adopted was to use its discretion under Rule of Court 475(4) to grant the applicant costs under Column 3 with no limiting rule to apply. The normal costs awarded in such an application would range between $\$ 100$ and $\$ 150$ and so the award in this case represented a significantly higher sum.

This case, which would seem to represent the law as it now stands in Alberta on this matter, thus steers a careful course between undue harshness, which would tilt the scales of justice too generously in favour of the judgment creditor and an unseemly laxness which would mean in effect that the court was disregarding an abuse of its process by the garnishee.

In conclusion, although garnishees would be unwise to ignore any garnishee summons served upon them, a judgment creditor should not expect any windfall if they do ignore them.

-PHILIP RAWORTH*

- LL.B. (Alta), articling with the firm of Emery Jamieson, Edmonton, Alberta. 